\title{
Debt Financing and Manufacturing Firms' Decision to Export: Evidence from Ghana
}

\author{
Benedict Afful Jr, PhD. ${ }^{1}$, Emmanuel Quarshie ${ }^{2}$, Joseph Kwasi Asafo ${ }^{3}$ \\ ${ }^{1}$ Department of Economic Studies, School of Economics, University of Cape Coast, Ghana \\ ${ }^{2}$ Cromwell Property Developers Ltd, East Legon, Accra, Ghana \\ ${ }^{3}$ Network for Socioeconomic Research and Advancement (NESRA), Accra, Ghana
}

\begin{abstract}
Adequate financial health indeed accelerates the entry of firms into the export market. Many firms, already in the market, have also fizzled out of export market completely due to lack of finance. It is quiet obverse that debt financing influences not only firm's performance but also firm's decision export. Hence, evaluating the relationship between debt financing and manufacturing firms' decision to export from Ghana have relevant policy implication in the context of developing country. To effectively address the objectives, the study employed the probit model on 377 manufacturing firms obtained from the World Bank Enterprise Survey data (Ghana). The study found that debt financing positively influences the decision to export. In other words, an increase in debt financing increases the firm's probability of exporting in Ghana. Whiles female top managers are less likely to export than their male counterparts, firms with large workforce are more likely to export. Firms with experienced top managers are also likely to export their products. In terms of location, firms in Tema exports more than firms in Accra and Takoradi. The study recommends that the financial market of Ghana be developed to enable manufacturing firms' source more external funds in the form of debt finance to enable them export.
\end{abstract}

Keywords - Ghana, Export, Cocoa, manufacturing, Finance

\section{INTRODUCTION}

$\mathrm{G}^{\mathrm{s}}$ hanaian firms export a significant number of key commodities and services. Among these commodities are: gold, cocoa, timber products, tuna, bauxite, aluminium, manganese ore, diamond, and horticulture. According to the Trading Economics (2020), China and Switzerland dominate Ghana's export destinations with percentage shares of 17 percent and 15 percent respectively. From the period of 1960 to 2019, total exports of goods and services on the average contributed 23.73 percent of GDP with a minimum of 3.34 percent in 1982 and a maximum of 48.8 percent in 2000 (World Development Indicators, 2020). It is not surprising to have the minimum and the maximum export contributions to GDP in these years given the support around those years. According to Jebuni, Oduro, Asante and Tsikata (1992), the contribution of export to GDP was low in 1982 because there was no automatic access to export finance although there were interesting policies. However, in the year 2000, the African Growth and Opportunity Act (AGOA) was launched with the aim of encouraging export-led growth, economic development and improve U.S. economic relations with Africa. With AGOA, many sensitization workshops were organized and attention was given to issues like exports financing-risk, access to finance, and financing export contracts and payment. Is the link between finance and export performance in the Ghana a coincident or a fact?

Existing literature suggests that adequate financial health accelerates the entry of firms into the export market. It is justifiable that high cost of entry into export markets, cost of transportation, cost of information on market, cost of developing products to satisfy foreign markets as well as costs of other inputs makes the activities of exporting firms costlier than domestic operators (Das, Roberts, \& Tybout, 2007). Most firms have fizzled out of export market completely due to lack of finance (Manova, 2008). Chaney (2005) and Manova (2008) both hold the view that debt financing influences a firm's decision to export.

Despite the various assertions made regarding the effect of the debt financing and export activities, there is a limited study (more particularly) on Ghana to ascertain the relationship between debt financing and exports in Ghana. It should be noted that firm-specific and country-specific characteristics are quite unique and differs from one country to another. Moreover, the challenges faced by Ghanaian firms in their export decisions are multifaceted and require a critical look. This study therefore attempts to investigate the link between debt financing and exports decisions of manufacturing firms in Ghana.

\section{LITERATURE REVIEW}

A study by Manova (2008) to analyse the effect of equity market liberalization on the export decision of 91 countries and shocks to external finance availability from the period 1980 to 1997 . The result indicated that trade liberalization increases export in sectors that are financially vulnerable through foreign finance. Also, the result shows that countries that liberalized their trade even with weak stock market are able to attract foreign equities which may cover up the low domestic finance. Likewise, the findings also indicated that strong equity market has the potential improving trade even in the face restrictive trade policy.

Minetti and Zhu (2011) and Bellone et al. (2010) analyzed the effect of lack of financial access on export activities. They explained that, firms with minimal credit constraints are more likely to export. These studies have argued that firms incur 
higher costs in an attempt to find potential customers in overseas market, effectively establish channels for distribution as well as adapt their products to the regulations and preferences of foreign markets. These factors tend to limit and demotivate a firm's entry to foreign markets as well as its export performance.

Becker, Chen and Greenberg (2013) examined the annual bilateral trading activities of 170 countries between 1970 and 1998. The study controlled for distance between importing and exporting countries, the existence of a common border and language differentials between two trading countries. By using the Ordinary Least Squares (OLS) regression technique, they found development of the financial sector to greatly influence exports. They therefore concluded that export promotion is highly dependent on the development of financial systems in domestic economies.

Alvarez and Lopez (2014) used firm level data from manufacturing firms in Chile from 1995 to 2002 to study the causal relationships that exist between access to finance and probability of exports. The study controlled for the volatility of real exchange rate to examine the relationship between access to finance and the probability of exporting activities. By employing a linear probability model, the results show that depreciation of the exchange rate increases export profitability and consequently increases the probability to export particularly with firms with larger financial requirements.

Fernandes, Ferro and Wilson (2014) examined the effect product standards on export decision of firms in 20 developing countries. The study assessed the effect of the introduction of sanitary measures in the export of 203 agricultural and food products between 2006-2010. Results obtained show that, a stricter and restrictive standard in the importing country relative to the exporting country reduces the probability for firms participating in foreign markets. Also, the study found smaller firms to be less likely to participate in new markets due to the existence of standards.

Olney (2016) examined the impact corruption on the selfselection phenomenon of firms into export markets. A heterogeneous model for the firm suggests that corruption reduces the probability that a particular firm sells locally as well as the probability to firms' export directly into foreign markets. These propositions were investigated using a panel dataset gathered on 23,000 firms from 80 developing countries. Results from an Instrumental Variable (IV) probit analysis reveal that, corruption reduces the probability that a firm will only trade locally since only the more productive firms have the ability to overcome the additional cost elements associated with a corrupt business environment. Furthermore, corruption was also found to decrease the probability of firms exporting directly.

Appreciable efforts have been made by earlier studies to investigate the factors which influence export decisions as well as the effect of debt financing on exports. However, these studies were conducted in developed countries as well as developing countries outside the African continent and Ghana in particular. The firm-specific and country-specific characteristics are quite unique and differ from one country to another. For example, the challenges such as indiscriminate charges by service providers, processes in obtaining licenses and permits from statutory bodies faced by Ghanaian firms in their export decisions are multifaceted and also differ from what other countries face. This study therefore seeks to fill this gap in literature of export decision making in Ghana.

\section{METHODOLOGY}

\subsection{Data}

Cross-sectional secondary data was used for the study. Specifically, the World Bank Enterprise Survey Data 2013 was used. The Enterprise Survey Data 2013 is the second round of its kind, with the first survey conducted in 2003. The Enterprise Survey covers 130,000 firms divided into manufacturing and services sections across 131 countries (World Bank, 2013). With regards to the Ghana survey, a total of 720 of firms were interviewed of which 377 were into manufacturing. This study focused on the manufacturing section and the motivation for this decision reflects the fact that most export decisions (comparing the two sectors) are undertaken by manufacturing firms in Ghana.

\subsection{Methods and model}

\section{Theoretical model}

Given the conditions of the domestic and global business environment, firms decide to export their produce or not. This makes the decision to export a dichotomous variable (Gujarati, 2004; Greene, 2008). The probit model is therefore adopted to address the objectives of the study. Among the choice models, the probit model is superior to the Linear Probability Model (LPM) (Johnston \& DiNardo, 1997).

In the spirit of Johnston and DiNardo (1997), Gujarati (2004), Greene (2008) and Maddala (2005) the probit model is espoused as follows:

$Y=\beta X+e$

Where:

$\mathrm{Y}=$ Desire outcome which is observed.

$X=$ the independent or control variables

$\beta=$ Coefficient of the explanatory variables

$e=$ the error term which normally distributed with a mean zero and unit variance.

With this model, the observed dummy variable, $Y$, is whether or not a firm export. While $Y^{*}$ is the tendency for a firm to export. This implies that when $\left(\mathrm{Y}^{*}>0\right)$ the firm export (Maddala, 2005, Gujarati, 2004; Greene, 2008; Hill et al., 2008). Given the normality of the probit distribution, the probability that $\mathrm{Y}^{*}$ is less than or equal to $\mathrm{Y}$ can be computed as follows: 
$P_{i}=P(Y=1 \mid X)=P\left(Y_{i}^{*} \leq Y_{i}\right)=P\left(Z_{i} \leq \beta X\right)=F(\beta X)$

Where

$\mathrm{P}=$ the probability that an event will occur

$P(Y=1 \mid X)=$ the probability that the firm will export.

$Z_{i}=$ the standard normal distribution variable

$\mathrm{F}=$ the standard normal cumulative distribution function. Specifically, $\mathrm{F}$ is represented as:

$F\left(Y_{i}\right)=\frac{1}{\sqrt{2 \pi}} \int_{-\infty}^{Y_{i}} e^{-z^{2} / 2} d z$

$F\left(Y_{i}\right)=\frac{1}{\sqrt{2 \pi}} \int_{-\infty}^{B X_{i}} e^{-z^{2} / 2} d z$

To obtain information on $\mathrm{Y}^{*}$, the inverse of equation (2) is taken. This is espoused as:

$$
\begin{aligned}
Y_{i} & =F^{-1}\left(Y_{i}\right)=F^{-1}\left(P_{i}\right) \\
& =\beta X_{i}
\end{aligned}
$$

Unlike the linear models, estimates of non-linear models such as the probit model in (7) cannot be interpreted as effects of the control variables on the regressand (Gujarati, 2004). Thus, to obtain one-unit change interpretation for the estimates of (7), the marginal effects are estimated. Greene (2008); Gujarati (2004) and Hill et al. (2008) specify the marginal effects functions as:

$\frac{d P(X)}{d X_{j}}=F(\beta X) \beta_{j}$

\section{Empirical Model}

Based on the theoretical and the empirical review forgoing, the empirical model that underpins the study is specified as follows:

$$
\begin{gathered}
Y=\beta_{0}+\beta_{1} \ln D F+\beta_{2} \ln E F+\beta_{3} G T M+\beta_{4} \ln F A+ \\
\beta_{5} \ln M E+\beta_{6} \ln L A B+\beta_{7} L O C+e \ldots(9)
\end{gathered}
$$

Where:

$\mathrm{Y}=\mathrm{A}$ dummy variable for the firm's decision to export, $\ln D F$ $=$ the natural logarithm of amount of Debt financing, $\ln E F=$ the natural logarithm of amount of equity financing, $\ln F A=$ the natural logarithm of Firm age, $\ln L A B=$ the natural logarithm of firm's workforce, GTM = dummy for gender of top manager, $\ln M E=$ the natural logarithm of Manager Experience, $L O C=$ Firm's location. $\beta_{1}, \beta_{2}, \beta_{3}, \beta_{4}, \beta_{5}, \beta_{6}$, and, $\beta_{7}$ are parameter estimates. The probit model estimated

\begin{tabular}{|c|c|c|}
\hline & $\begin{array}{l}\text { firms from both financial and } \\
\text { non-financial institutions. }\end{array}$ & \\
\hline Equity Finance (EF) & $\begin{array}{l}\text { It is sum of equity stocks } \\
\text { sourced by the firm. }\end{array}$ & + \\
\hline Firm Age (FA) & $\begin{array}{l}\text { How long the firm has existed } \\
\text { since incorporation. }\end{array}$ & +/- \\
\hline $\begin{array}{l}\text { Manager's Experience } \\
\text { (ME) }\end{array}$ & $\begin{array}{l}\text { Years of work experience of the } \\
\text { firm top manager. }\end{array}$ & + \\
\hline Firms workforce (LAB) & $\begin{array}{l}\text { The number of people hired by } \\
\text { the firm }\end{array}$ & + \\
\hline $\begin{array}{l}\text { Gender of Top } \\
\text { Manager (GTM) }\end{array}$ & $1=$ female, $0=$ male & +/- \\
\hline Location (LOC) & $\begin{array}{l}0=\text { Accra, } 1=\text { Northern region, } \\
2=\text { Takoradi, } 3=\text { Tema }\end{array}$ & $+/-$ \\
\hline
\end{tabular}
with the maximum likelihood techniques.

Table 1: Definition of Variables and Expected Signs

\begin{tabular}{|l|l|l|}
\hline Variable & Definitions & $\begin{array}{l}\text { Expected } \\
\text { Sign }\end{array}$ \\
\hline Export decision (Y) & $\begin{array}{l}\text { 1= if the firm exports and 0 if } \\
\text { otherwise. }\end{array}$ & \\
\hline Debt Finance (DF) & It is the sum of loans taken by & + \\
\hline
\end{tabular}

Source: Author's Construct (2021)

IV.

\section{RESULTS AND DISCUSSIONS}

\section{Descriptive Statistics}

The study provides summary statistics on the location, gender of top manager of the firm in question, firm size, and debt financing sources.

Table 2: Descriptive statistics

\begin{tabular}{|c|c|c|}
\hline Variable & Frequency & $\begin{array}{c}\text { Percentages } \\
(\%)\end{array}$ \\
\hline Firms location & & \\
\hline Accra & 181 & 48.01 \\
\hline Tema & 78 & 20.69 \\
\hline North & 91 & 24.14 \\
\hline Takoradi & 27 & 7.16 \\
\hline Gender of Top Manager & & \\
\hline Males & 323 & 85.68 \\
\hline Females & 54 & 14.32 \\
\hline Firm Size & & \\
\hline Small & 253 & 67.11 \\
\hline Medium & 88 & 23.34 \\
\hline Large & 36 & 9.55 \\
\hline Source Debt Financing & & \\
\hline Borrowed from Banks & 286 & 75.86 \\
\hline Borrowed from Non-Bank Financial & 37 & 9.81 \\
\hline Institutions & 38 & 10.08 \\
\hline Purchases on Credit from Suppliers & 16 & 4.25 \\
\hline Others (friends and relatives) & & \\
\hline & & \\
\hline
\end{tabular}

Source: Author's own calculations based on World Bank Enterprise Survey, 2013

From Table 2, 48.01 percent 181 of the manufacturing firms operate in Accra, the capital city of Ghana. In addition, 20.69 percent of the firms undertake their production activities in Tema. In the three Northern regions, 24.14 percent of the manufacturing firms operate in that section of the country whilst 7.16 percent of manufacturing firms operate in Takoradi in the Western region.

Also, 323 of the top managers, representing 85.68 percent are males whilst the remaining 14.32 percent are females. This suggest that males are about six times more than their female 
counterparts, confirming the (GLSS 6 Report, 2014) that females lack superior labour market skills in Ghana.

By workforce, the World Bank Enterprise Survey categorizes firms into Small, Medium and Large; where small firms have between 5 and 19 employees. Medium firms' employee between 20 and 99 people whilst large firms' employee more than 100 people. Majority of the firms sampled are small and this could be due to the cost of operation in this sector (i.e. manufacturing). The survey revealed that 67.11 percent of the firms are small whilst 23.34 percent are medium. Also, the data shows that 9.55 percent of the firms sampled are large.

The Survey showed that majority of the firms financed their activities by loans taken from commercial banks. The data shows that 75.86 percent of the firms (286) borrowed from banks to finance their activities. Another 10.08 percent of the firms source funds by purchasing on credit from suppliers whilst 9.81 percent source funds from Non-Bank financial institutions. The Table 2 also shows that 4.25 percent financed their operations from friends and relatives.

\section{Debt Financing and Export Decisions}

The estimates reveal that the probit model is statistically significant at 1 percent. With the exception of equity financing and firm age, the results show that debt financing, gender of top manager, management experience, firm location, and labour have a significant effect on a firm's decision to export.
In line with Calabrese (2011), Nyamita (2014), Anderson et al. (2004), Tannous (1997), Kawas (1997), the results show that firms that embark on debt financing are more likely to export their products to the global market. Table 4 reveals that debt financing is positive and statistically significant at 10 percent. Specifically, a percentage increase in debt financing increases exports by 10.21 percent. This implies that if firms make use of available debt financing channels (e.g. borrow from bank or non-bank financial institutions), they can penetrate and sustain their existence in the global market. Access to debt finance increases the capital needed for production hence producing at a relative lower cost compared to their competitors. The low production cost may result in them charging lower price hence competitive advantage in terms of market size in the global market.

In accordance with economic theory (Varian, 1992), the results also showed that firms with large workforce (labour) are more likely to export their products. This emanates from the positive relationship between labour and the decision to export. Workforce is statistically significant at 1 percent. A percent increase in labour increases the decision to export by 69.8 percent. This agrees with Anderson et al. (2004). The result suggests that larger firms are more likely to exports their produce. This shows that firms that have the large labour are more likely to produce more to feed the local market and have excess to export compared to firms with smaller number of workers.

Table 4: Estimates of Probit Model

\begin{tabular}{|c|c|c|c|c|c|c|}
\hline Variable & Coefficient & $\begin{array}{c}\text { Standard } \\
\text { Error }\end{array}$ & P-value & $\begin{array}{c}\text { Marginal } \\
\text { effects }\end{array}$ & Standard error & P-value \\
\hline Debt Financing & $0.166^{*}$ & 0.1021 & 0.0990 & $0.1021^{*}$ & 0.09941 & 0.0981 \\
\hline Equity Financing & 2.451 & 0.2100 & 0.1240 & 2.152 & 1.9854 & 0.1104 \\
\hline Gender of top manager & $-1.345^{*}$ & 0.8754 & 0.0871 & $-1.412 *$ & 0.7454 & 0.0784 \\
\hline Firm Age & 0.041 & 0.3241 & 0.1240 & 0.501 & 0.2015 & 0.1190 \\
\hline Management Experience & $0.245^{*}$ & 0.987 & 0.0741 & $0.231 * *$ & 0.877 & 0.0541 \\
\hline Labour & $0.841 * * *$ & 0.2111 & 0.000 & $0.698 * * *$ & 0.2312 & 0.0000 \\
\hline Firm Location & & \multicolumn{2}{|c|}{ Base $=$ Accra } & & & \\
\hline 1. North & 8.975 & 1.3541 & 0.5612 & 9.0105 & 1.254 & 0.4444 \\
\hline 2. Takoradi & $-0.610^{*}$ & 0.0212 & 0.0980 & $-0.170^{*}$ & 0.0241 & 0.0891 \\
\hline 3. Tema & $0.554 * *$ & 0.1210 & 0.0400 & $0.271 * *$ & 0.1424 & 0.0222 \\
\hline \multicolumn{7}{|c|}{ Observation } \\
\hline \multicolumn{7}{|c|}{ Heteroskedasticity Test: Breusch-Pagan-Godfrey } \\
\hline \multicolumn{2}{|l|}{ F-statistic } & 1.261596 & \multicolumn{2}{|c|}{ Prob. F $(6,195)$} & \multicolumn{2}{|c|}{0.2946} \\
\hline \multicolumn{2}{|c|}{ Obs*Pseudo R-squared } & 9.848180 & \multicolumn{2}{|c|}{ Prob. Chi-Square (6) } & \multicolumn{2}{|c|}{0.2758} \\
\hline Scaled explained SS & \multicolumn{2}{|c|}{15.34745} & \multicolumn{2}{|c|}{ Prob. Chi-Square (6) } & \multicolumn{2}{|c|}{0.0527} \\
\hline
\end{tabular}

Source: Author's own calculations based on World Bank Enterprise Survey, 2013

The model further reveals that gender is statistically significant at $10 \%$ in driving the decision to export. This finding also agrees with Anderson et al. (2004). The estimates show that firms with top female managers are less likely to export their product compared to firms with male top managers. In terms of magnitude, female top managers are 1.41 percent less likely to export compared to their male 
counterparts. It suggests that female managers are less likely to take risk in the international market than male managers.

In addition, firms with experienced managers are more likely to export their products compared to inexperienced managers. An additional year of experience increases the firms export decision by 23.1 percent. The result is statistically significant at 10 percent and confirms the findings of Anderson et al. (2004).

In terms of the location of the firm and using Accra as the reference category, the results show that firms located in Tema are 0.27 percent more likely to export compared to firms in Accra. However, firms in Takoradi are 0.17 percent less likely to export compared to firms located in Accra. These are statistically significant at 10 percent respectively. Since Tema is designated as industrial zone and much closer to the Tema port, it this result is expected. The result of Accra being more likely to export than Takoradi was not expected but could explained by the fact that there are more manufacturing firms in Accra than in Takoradi.

\section{CONCLUSION AND RECOMMENDATIONS}

Export activities are important for the health of the entire economy. Specifically, it aids in wealth creation for those involved. It also cushions the aggregate economy against exchange rate fluctuations. Further, it provides employment in the domestic economy. Acceleration of export activities is, however, dependent on adequate and sustainable financing. Debt financing is one outlet of financing export activities of firms in Ghana and in other jurisdictions.

With the general objective of uncovering the effect of debt financing on export decision of manufacturing firms in Ghana, the study concludes that the larger the debt financing, the higher the likelihood of a manufacturing firm willing to export. In other words, an increase in debt financing increases the manufacturing firms' likelihood to export. Firms with large workforce and more experienced top manager are more likely to export their produce. Firms with female top managers are less likely to export than their male counterparts. In terms of location, firms in Tema and Takoradi are more and less likely to export than manufacturing firms in Accra.

Given the above conclusions, the study recommends that the financial market of Ghana be developed. This can be done by designing a unique traceable identity for all firms in the country so that banks and other financial institutions would not have problems advancing loans to them. By so doing, firms can easily access loans or credits to enable them engage in exporting activities. Government should also set up fund accessible by manufacturing firms to aid in exporting activities.

\section{REFERENCES}

[1] Alvarez, R. \& López, R. A. (2014). Exporting and Performance: Evidence Chilean Plants. Canadian Journal of Economics, 38(4), 1384-1400.
[2] Andersson, S., Gabrielsson, J. \& Wictor, I. (2004). International Activities in Small Firms: Examining Factors Influencing the Internationalization and Export Growth of Small Firms. Canadian Journal of Administrative Sciences, 21(1) 22-34.

[3] Becker, B., Chen, D. \& Greenberg, J. (2013). Financial development, fixed costs and international trade. Review of corporate finance studies 2: 1-28.

[4] Bellone, F., Musso, P., Nesta, L. \& Schiavo, S. (2010). Financial Constraints and Firm Export Behaviour. The World Economy, 33, 347-373.

[5] Calabrese, T. D. (2011). Testing Competing Capital Structure Theories of Nonprofit Organizations. Public Budgeting \& Finance, 31 (3): 119-143.

[6] Calice, P., Chando, V. M., \& Sekioua, S. (2012). Bank financing to small and medium enterprises in east Africa: findings of a survey in Kenya, Tanzania, Uganda and Zambia.

[7] Chaney, T. (2005). Liquidity Constrained Exporter. University of Chicago paper.

[8] Das, S., Roberts, M. J., \& Tybout, J. R. (2007). Market entry costs, producer heterogeneity, and export dynamics. Econometrica, 75(3), 837-873.

[9] Factbook, C. I. A. (2012). Central Intelligence Agency. Benin, URL: https://www. cia. gov/library/publications/the-worldfactbook/geos/bn. html.

[10] Fernandes, A. M, Ferro, E. \& Wilson, J. S. (2014). Product Standards: Do they affect Firms' Export Decisions? The world Bank. Accessed on 1 September 2017 from http://www.etsg.org/ETSG2014/Papers/447.pdf

[11] Ghana Export Promotion Authority, (2014). Non Traditional Export Sector Performance by Sub-Sectors, GEPA: Accra.

[12] Greene, H. W. (2008). Econometric analysis. 6th ed. Upper Saddle River, New Jersey: Prentice Hall.

[13] Gujarati, N. D. (2004). Basic econometrics. The McGraw- Hill.

[14] Jebuni, C. D., Oduro, A. D., Asante, Y. O., \& Tsikata, G. K. (1992). Diversifying exports: the supply response of nontraditional exports to Ghana's economic recovery programme. Overseas Development Institute.

[15] Johnston, J., \& DiNardo, J. (1997). Econometric Methods.

[16] Kawas, R. B. (1997). Export Financing. Economic Development Review, 15 (2), 61.

[17] Manova, K. (2008). Credit constraints, equity market liberalization and international trade. Journal of International Economics 76: 33-47.

[18] Mineti, R. \& Ch. Zhu., S. (2011). Credit Constraints and Firm Export: Microeconomic: Evidence from Italy. Journal of International Economics, 83, 109-125.

[19] Nyamita, M. (2014). Factors influencing debt financing and its effects on financial performance of state corporations in Kenya. $A$ Doctoral Thesis, Durban University of Technology.

[20] Olney, W. W. (2016). Impact of corruption on firm-level export decisions. Economic Inquiry, 54(2), 1105-1127.

[21] Tannous, G. F. (1997). Financing export activities of small Canadian business: Exploring the constraints and possible solutions. International Business Review, 6(4), 411-431.

[22] Trading Economics (2020). Ghana Exports by Country in U.S. Dollars, According to the United Nations COMTRADE Database on International Trade.

[23] Varian, H. (1992). Microeconomic theory. W. W. Norton \& Company, New York.

[24] World Bank (2013). World Bank Enterprise Survey. 